\title{
Efektivitas Penambahan Karbon Aktif Cangkang Kelapa Sawit (Elaeis Guineensis) dalam Proses Filtrasi Air Sumur
}

\section{Effectiveness Of Addition Of Activated Carbon Shell Oil Palm (Elaeis Guineensis) Filtration Process Water In Wells}

\author{
Muhammad Fadhillah, Denai Wahyuni
}

Program Studi Ilmu Kesehatan Masyarakat STIKes Hang Tuah Pekanbaru

\begin{abstract}
ABSTRAK
Dampak dari pencemaran air dapat menyebabkan terjadinya ketidakseimbangan ekosistem dan dapat sebagai pembawa penyakit menular. Oleh karena itu perlu dilakukan penjernihan terhadap air sebelum digunakan untuk meningkatkan kualitas air. Salah satu yang dapat digunakan untuk penjernihan air adalah arang aktif cangkang kelapa sawit (Elaeis guineensis). Tujuan penelitian ini adalah: Untuk mengetahui efektifitas penambahan arang aktif cangkang kelapa sawit dalam proses filtrasi terhadap karakter fisik (kekeruhan, $\mathrm{Ph}$, bau dan rasa) air sumur. Penelitian ini bersifat eksperimen dengan menggunakan Rancangan Acak Lengkap (RAL). Filtrasi air sumur dilakukan dengan 4 perlakuan dan 3 kali ulangan yaitu: 1). tanpa melewati saringan pasir (kontrol), 2). melewati saringan pasir tanpa arang aktif cangkang kelapa sawit, 3). melewati saringan pasir dengan penambahan arang aktif cangkang kelapa sawit dengan ketebalan $10 \mathrm{~cm}$, dan 4). ketebalan $15 \mathrm{~cm}$. One way ANOVA digunakan dalam analisis data. Analisa kekeruhan adalah 100,0; 50,5; 40,4; dan 47,5 berturut-turut untuk kontrol, tanpa arang aktif, dengan arang aktif $10 \mathrm{~cm}$ dan dengan arang aktif $15 \mathrm{~cm}$. Hasil uji menunjukkan perbedaan yang bermakna antara kekeruhan air kontrol dengan kekeruhan dari perlakuan lainnya. $\mathrm{pH}$ air $<7$ menjadi 8,99. Analisa bau dan rasa didapatkan air yang melewati proses filtrasi dengan penambahan arang aktif menghilangkan bau dan rasa pada air tersebut. Penambahan arang aktif cangkang kelapa sawit dengan ketebalan $10 \mathrm{~cm}$ cukup efektif dalam proses filtrasi air sumur dan dapat memperbaiki kualitas fisik air.
\end{abstract}

Kata Kunci : Cangkang Kelapa Sawit dan Filtrasi, Karbon Aktif

\section{ABSTRACT}

The impact of water pollution can cause an imbalance of the ecosystem and a contagious disease. So,it is necessary to refine the water before it is used to improve water quality. One that can be used to purify water is palm shell activaited charcoal (Elaeisguineensis). The purpose of this study is to determine the effectiveness of the addition of activated charcoal palm shells in the filtration process of the physical characteristics (turbidity, Ph, smell and taste) of the well. This research is an experiment using a completely randomized design (CRD). Well water filtration is performed with 4 treatments and 3 repetitions namely: 1). without passing through the sand filter (control), 2).through the sand filter without palm shell activaited charcoal, 3). through the filter sand with the addition of palm shell activaited charcoalwith a thickness of $10 \mathrm{~cm}$, and 4). thickness of $15 \mathrm{~cm}$. One way ANOVA was used for data analysis. The turbidityanalysis is 100.0; 50.5; 40.4; and 47.5 respectively for the control, without activated charcoal, $10 \mathrm{~cm}$ and $15 \mathrm{~cm}$ with activated charcoal. The result showed that there is no significant differences the turbidity of the contratedwater with the turbidity of other treatments. water $p H<7$ becomes 8.99. Analysis found the smell and taste of water through the filtration process with the addition of activated charcoal to eliminate odor and taste in the water. The addition of palm shell activaited charcoal with a thickness of $10 \mathrm{~cm}$ is quite effective in well water filtration process and can improve the physical quality of the water.

\section{Keywords : Activated Carbon, Shells Palm Oil and Filtration.}

\section{PENDAHULUAN}

Air merupakan zat yang paling penting dalam kehidupan setelah udara. Sekitar tiga per empat bagian tubuh kita terdiri atas air, tidak seorangpun dapat bertahan hidup lebih dari 4-5 hari tanpa minum air. Selain itu, air juga digunakan untuk memasak, mencuci, mandi, dan membersihkan kotoran yang ada di sekitar rumah. Air juga digunakan untuk keperluan industri, pertanian, pemadam kebakaran, tempat rekreasi, transportasi dan lain-lain (Mubarak dan Chayatin, 2008). Seiring dengan perkembangan zaman sangat sulit untuk mendapatkan kualitas air yang baik akibat

${ }^{1}$ Alamat Korespodensi:_Denai Wahyuni, Email : denaiwahyuni69@gmail.com

Jurnal Kesehatan Komunitas, Vol. 3, No. 2, Mei 2016

Page 93 
banyaknya pencemaran-pencemaran yang terjadi di lingkungan kita yang menyebabkan kualitas air menjadi buruk.

Kusnaedi dalam Sulfami (2010), menyatakan bahwa untuk jangka pendek kualitas air yang tidak baik dapat mengakibatkan muntaber, diare, kolera, tipus atau disentri. Hal ini dapat terjadi pada keadaan sanitasi lingkungan yang kurang baik. Bila air tanah dan air permukaan tercemar oleh kotoran, maka mikroorganisme akan tersebar ke sumber air yang dipakai untuk keperluan rumah tangga. Oleh karena itu, pemeliharaan akan kualitas dan kuantitas air sangatlah penting demi suatu kelestarian lingkungan yang berkelanjutan.

Sampai saat sekarang masyarakat masih banyak menggunakan sumur sebagai sumber persediaan air bersih, sebagai aktifitas dalam kehidupan sehari-hari dan sebagai sumber air minum. Tetapi air sumur pada saat sekarang banyak yang sudah tercemar baik yang bersifat organik maupun anorganik sehingga air sumur pada masyarakat menjadi keruh. Air minum yang ideal harus mempunyai karakteristik seperti jernih, tidak berwarna, tidak berasa, tidak berbau, tidak mengandung zat kimia yang dapat mengubah fungsi tubuh, tidak membahayakan kesehatan manusia, tidak meninggalkan endapan pada seluruh jaringan distribusinya, tidak korosif dan lain-lain. Hal ini bertujuan untuk mencegah terjadinya serta meluasnya penyakit bawaan air (Soemirat, 2000).

Untuk mengurangi dampak pada air tersebut maka harus dilakukan pengolahan dan penjernihan terutama air sumur agar kualitas air minum tetap baik dan dapat digunakan dalam kehidupan sehari-hari. Penjernihan perlu dilakukan terhadap air sebelum digunakan untuk meningkatkan kualitas air. Penjernihan air yang selama ini lazim digunakan adalah secara kimia dengan disinfektan dan koagulan menggunakan bahan kimia yaitu klorin, kaporit dan tawas. Akan tetapi penggunaan klorin, kaporit dan tawas dalam jangka panjang dapat menimbulkan iritasi. Salah satu cara untuk mengurangi resiko dari penggunaan klorin, kaporit dan tawas tersebut adalah dengan mencari alternatif untuk penjernihan air yang bersifat alami dan ramah lingkungan. Selama ini pengolahan dengan menggunakan bahan alami belum terlalu populer dalam masyarakat, padahal sangat banyak tanaman atau tumbuhan yang dapat digunakan dalam proses penjernihan air secara alami.

Salah satu caranya adalah dengan mengadsorpsi dan filtrasi. Hal ini dilakukan dengan cara penambahan adsorben (karbon aktif) ke dalam saringan pasir lambat, sehingga limbah yang terdapat dalam air akan disaring dan juga diserap ke dalam pori-pori karbon aktif. Cangkang kelapa sawit (Elaeis guineensis) diduga merupakan salah satu bahan yang dapat digunakan dalam proses penjernihan air karena cangkang kelapa sawit dapat dibuat menjadi arang aktif. Sembiring dan Sinaga (2003) dalam penelitiannya tentang efektifitas biji kelor pada pengolahan air sumur tercemar limbah domestik menjelaskan bahwa arang aktif merupakan senyawa karbon amorph, yang dapat dihasilkan dari bahanbahan yang mengandung karbon atau dari arang yang diperlakukan dengan cara khusus untuk mendapatkan permukaan yang lebih luas. Luas permukaan arang aktif berkisar antara 300-3500 $\mathrm{m} 2 /$ gram dan ini berhubungan dengan struktur pori internal yang menyebabkan arang aktif mempunyai sifat sebagai adsorben

Di Provinsi Riau, kelapa sawit merupakan komoditas primadona yang banyak diusahakan oleh masyarakat maupun badan usaha. Berdasarkan data Dinas Perkebunan Provinsi Riau (2013), perkembangan luas areal perkebunan kelapa sawit meningkat secara tajam yakni 966.786 ha pada tahun 2000 meningkat menjadi 2.258 .553 ha pada tahun 2012. Selama periode tahun 2000-2012 tingkat pertumbuhan rata-rata sebesar 8,08 persen per tahun, sementara komoditas perkebunan lainnya seperti karet dan kelapa justru mengalami penurunan. Perluasan areal perkebunan diikuti dengan peningkatan produksi berupa tandan buah segar (TBS). Produksi TBS sebesar 1.792.481 ton pada tahun 2000 meningkat menjadi 7.047.221 ton pada tahun 2012 dengan pertumbuhan rerata per tahun sebesar 12,1 persen. Aktivitas kegiatan perkebunan kelapa sawit tersebut didukung oleh pabrik kelapa sawit (PKS) sebanyak 146 unit yang tersebar di berbagai kabupaten/kota di Propinsi Riau (Syahza, 2013).

Moenif (2012), mengatakan di Provinsi Riau PKS berjumlah 146 dengan total kapasitas produksi Pengolahan 6.137 Ton/jam TBS. Dari total kapasitas produksi PKS dapat mengasilkan Fiber dan Shell sebesar 13.010 Ton/jam dan Limbah cair 37.822 $\mathrm{m} 3 /$ jam. Jadi Potensi arang aktif yang bisa dihasilkan dari cangkang kelapa sawit di Provinsi Riau cukuplah banyak, oleh karena itu peneliti tertarik untuk meneliti tentang efektivitas penambahan arang aktif cangkang kelapa sawit (Elaeis guineensis) dalam proses filtrasi terhadap karakter fisik (kekeruhan, $\mathrm{pH}$, bau dan rasa) air sumur.

\section{METODE}

Penelitian ini dilakukan di Laboratorium UPT Dinas Kesehatan dan Lingkungan Provinsi Riau dan Laboratorium Universitas Abdurrab Pekanbaru pada bulan Mai 2015

Jenis Penelitian ini adalah eksperimen dengan menggunakan metode rancangan acak lengkap (RAL) dengan Empat perlakuan dan Tiga kali ulangan, yaitu : $\mathrm{K}_{0}=$ Tanpa melewati saringan pasir lambat (kontrol) $\mathrm{K}_{1}=$ Melewati Saringan Pasir Tanpa Arang Aktif Cangkang Kelapa Sawit, $\mathrm{K}_{2}=$ Melewati Saringan Pasir Dengan Penambahan Arang Aktif 
Cangkang Kelapa Sawit dengan ketebalan $10 \mathrm{~cm}$ dan $\mathrm{K}_{3}=$ Melewati Saringan Pasir Dengan Penambahan Arang Aktif Cangkang Kelapa Sawit dengan ketebalan $15 \mathrm{~cm}$ (Gambar 1).

Alat yang digunakan adalah: tanur, toples, $\mathrm{pH}$ meter, turbiditymeter, ember penampung air, ember penimba air, botol minuman $600 \mathrm{ml}$, pipa paralon 8 inci, gergaji besi, pisau, lem pipa dan alat penggilingan. Sedangkan bahan yang digunakan adalah: cangkang kelapa sawit (Elaei guineensis), air sumur, batu kerikil, pasir, kain kasa/ penyaring, ijuk.

Pengambilan sampel air sebagai percobaan dilakukan pada air sumur yang memiliki kriteria fisik yang buruk pada permukaan, bagian tengah dan bagian dasar sumur. Kemudian dimasukkan pada ember penampungan lalu dihomogenkan dan ditutup rapat.

Pembuatan Arang Aktif dari cangkang kelapa sawit (Elaeis guineensis), dilakukan dengan cara karbonisasi dan aktivasi. Cangkang kelapa sawit dicuci dengan air bersih dan dikeringkan, Selanjutnya dilakukan proses pembakaran sampai menjadi arang kemudian didinginkan lalu diaktivasi di laboratorium menggunakan tanur suhu $800^{\circ} \mathrm{C}$ selama 30 menit, didinginkan dan digiling lalu disimpan dalam toples.

Pembuatan Saringan Pasir dengan menyiapkan paralon diameter 8 inci sepanjang 1 meter, tutup salah satu lobang dan disusun bahan tersebut seperti pada gambar berikut:

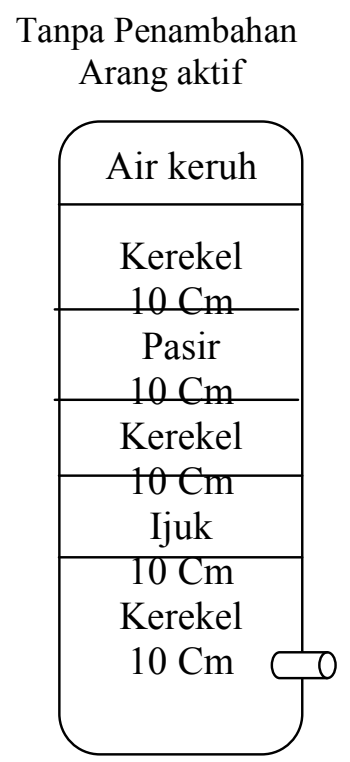

Dengan Penambahan Arang Aktif

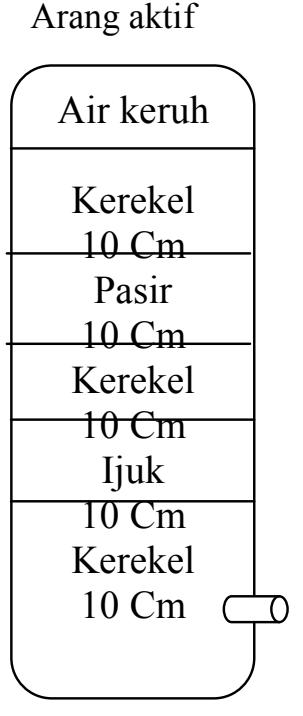

\begin{tabular}{|c|c|}
\hline $10 \mathrm{~cm}$ & $15 \mathrm{~cm}$ \\
\hline Air keruh & Air keruh \\
\hline $\begin{array}{c}\text { Kerekel } 10 \\
\mathrm{Cm}\end{array}$ & $\begin{array}{c}\text { Kerekel } 10 \\
\mathrm{Cm}\end{array}$ \\
\hline Pasir $10 \mathrm{Cm}$ & Pasir $10 \mathrm{Cm}$ \\
\hline Kerekel & Kerekel \\
\hline $10 \mathrm{Cm}$ & $10 \mathrm{Cm}$ \\
\hline Arang Aktif & Arang Aktif \\
\hline $10 \mathrm{Cm}$ & $15 \mathrm{Cm}$ \\
\hline Tjuk $10 \mathrm{Cm}$ & Tjuk $10 \mathrm{Cm}$ \\
\hline Kerekel & Kerekel \\
\hline $10 \mathrm{Cm}$ & $10 \mathrm{Cm}$ \\
\hline
\end{tabular}

\section{Gambar 1 : Saringan pasir lambat pada proses filtrasi air sumur}

Prosedur pengujian dilakukan dengan menyiapkan saringan pasir lambat yang telah dirancang dan siapkan 3 botol minuman untuk menampung air yang keluar dari saringan pasir lambat. Masukkan air keruh tersebut pada setiap saringan pasir dan air yang telah tersaring dalam botol ditutup lalu diperiksa di laboratorium. Perhitungan kekeruhan menggunakan Turbidymeter, dan perhitungan $\mathrm{pH}$ air menggunakan $\mathrm{pH}$ meter. Perhitungan Bau dan Rasa dengan taste panel (5-6 Orang). Hal tersebut dilakukan pada pengulangan kedua, dan ketiga

Analisa data menggunakan Analisa Varians dengan RAL (Rancangan Acak Lengkap). Kemudian dilanjutkan dengan uji One Way Anova program SPSS.

\section{HASIL}

Penelitian ini dilakukan tiga tahapan proses yaitu: pembuatan karbon aktif, membuat saringan pasir dan analisis dari proses filtrasi dengan menambahkan arang aktif. Menurut Kurakane (1999), pembuatan karbon aktif melibatkan dua proses yaitu proses karbonisasi dan aktivasi. Selama proses karbonisasi komponen yang mudah menguap hampir hilang. Aktivasi dapat dilakukan dengan dua cara yaitu aktifasi kimia dan aktifasi fisika. Hasil analisa dari proses filtrasi adalah sebagai berikut:

\section{Kekeruhan}

Proses filtrasi dengan penambahan arang aktif cangkang kelapa sawit (Elaeis guineensis) setebal 10 $\mathrm{cm}$ didapatkan hasil yang paling baik. Hasil analisis menunjukkan ada perbedaan yang bermakna pada tingkat $(p<0,05)$ pada tingkat kekeruhan air sebelum dan sesudah melakukan proses filtrasi (Tabel 1)

Tabel 1. Hasil Analisa Kekeruhan dari Proses Filtrasi

\begin{tabular}{lc}
\hline Perlakuan & $\begin{array}{c}\text { Nilai } \\
\text { Total } \\
\text { Unit }\end{array}$ \\
\hline Kontrol & $100,04 \mathrm{a}$ \\
Tanpa arang aktif & $50,47 \mathrm{~b}$ \\
Dengan penambahan arang aktif $10 \mathrm{~cm}$ & $40,40 \mathrm{~b}$ \\
Denganpenambahan arang aktif $15 \mathrm{~cm}$ & $47,47 \mathrm{~b}$ \\
\hline
\end{tabular}

Page 95 
Ket : Angka-angka yang diikuti oleh huruf yang sama dinyatakan tidak berbeda nyata pada taraf $5 \%$ uji DMNRT

\section{pH Air}

Proses filtrasi dengan penambahan arang aktif cangkang kelapa sawit (Elaeis guineensis) dapat menaikkan nilai $\mathrm{pH}$ air dan diduga dapat memperbaiki kualitas air yang bersifat asam. Hasil analisis menunjukkan terdapat perbedaan yang signifikan $\mathrm{pH}$ air sebelum dan sesudah melakukan proses filtrasi dengan arang aktif (Tabel 2)

Tabel 2. Hasil Analisa pH dari Proses Filtrasi

\begin{tabular}{cc}
\hline Perlakuan & Nilai NTU \\
\hline Kontrol & $6,21 \mathrm{~b}$ \\
Tanpa arang aktif & $5,77 \mathrm{~b}$ \\
Dengan penambahan & $9,02 \mathrm{a}$ \\
arang aktif $10 \mathrm{~cm}$ & \\
Denganpenambahan & $8,99 \mathrm{a}$ \\
arang aktif $15 \mathrm{~cm}$ & \\
\hline
\end{tabular}

Ket : Angka-angka yang diikuti oleh huruf yang sama dinyatakan tidak berbeda nyata pada taraf $5 \%$ uji DMNRT

\section{Bau}

Hasil analisis bau air pada 6 orang responden menunjukkan bahwa nilai bau pada kontrol atau tanpa melewati proses filtrasi adalah semua responden mengatakan masih berbau, proses filtrasi tanpa penambahan arang aktif cangkang kelapa sawit ratarata mengatakan masih berbau, pada proses filtrasi dengan penambahan arang aktif kelapa sawit $10 \mathrm{~cm}$ dan $15 \mathrm{~cm}$ semua responden mengatakan tidak berbau, Dengan demikian proses filtrasi dengan penambahan arang aktif cangkang kelapa sawit (Elaeis guineensis) dapat menghilangkan bau pada air tersebut (Tabel 3).

Tabel 3: Hasil analisa bau pada air dengan lembar ceklis pada enam orang responden:

\begin{tabular}{ccccccc}
\hline \multirow{2}{*}{ Perlakuan } & \multicolumn{6}{c}{ Ulangan } \\
\cline { 2 - 7 } & \multicolumn{2}{c}{ I } & \multicolumn{2}{c}{ II } & \multicolumn{2}{c}{ III } \\
\cline { 2 - 7 } & Berbau & Tidak & Berbau & Tidak & Berbau & Tidak \\
\hline Kontrol & 6 org & - & 6 org & - & 6 org & - \\
\hline Tanpa penambahan arang aktif & 5 org & 1 org & 4 org & 2 org & 2 org & 4 org \\
\hline Dengan penambahan Arang aktif $10 \mathrm{Cm}$ & - & 6 org & - & 6 org & - & 6 org \\
\hline Dengan penambahan arang aktif $15 \mathrm{Cm}$ & - & 6 org & - & 6 org & - & 6 org \\
\hline Suyyyyy
\end{tabular}

Sumber data: Olahan 2015

\section{Rasa}

Hasil analisis rasa pada 6 orang responden menunjukkan bahwa nilai rasa pada kontrol atau tanpa melewati proses filtrasi adalah semua responden mengatakan masih berasa, proses filtrasi tanpa penambahan arang aktif cangkang kelapa sawit rata- rata mengatakan masih berasa, pada proses filtrasi dengan penambahan arang aktif kelapa sawit $10 \mathrm{~cm}$ dan $15 \mathrm{~cm}$ semua responden mengatakan tidak berasa, Dengan demikian proses filtrasi dengan penambahan arang aktif cangkang kelapa sawit (Elaeis guineensis) dapat menghilangkan rasa pada air tersebut (Tabel 4).

Tabel 4: Hasil Analisa Rasa dari Proses Filtrasi

\begin{tabular}{cccccccc}
\hline \multirow{2}{*}{ Perlakuan } & \multicolumn{4}{c}{ Ulangan } \\
\cline { 2 - 7 } & \multicolumn{2}{c}{ I } & \multicolumn{2}{c}{ II } & \multicolumn{2}{c}{ III } \\
\cline { 2 - 7 } & Berasa & Tidak & Berasa & Tidak & Berasa & Tidak \\
\hline Kontrol & 6 org & - & 6 org & - & 6 org & - \\
\hline Tanpa penambahan arang aktif & 6 org & - & 5 org & 1 org & 4 org & 2 org \\
\hline Dengan penambahan Arang aktif 10 Cm & - & 6 org & - & 6 org & - & 6 org \\
\hline Dengan penambahan arang aktif 15 Cm & - & 6 org & - & 6 org & - & 6 org \\
\hline
\end{tabular}

Sumber data: Olahan 2015

\section{PEMBAHASAN}

\section{Kekeruhan}

Air dikatakan keruh, apabila air tersebut mengandung begitu banyak partikel bahan yang tersuspensi sehingga memberikan warna/rupa yang berlumpur dan kotor. Bahan-bahan yang menyebabkan kekeruhan ini meliputi: tanah liat, lumpur, bahanbahan organik yang tersebar secara baik dan partikel- partikel kecil yang tersuspensi lainnya. Kekeruhan merupakan sifat optis dari suatu larutan, yaitu hamburan dan absorpsi cahaya yang melaluinya (Suhartana, 2006).

Kualitas air yang baik adalah jernih (bening) dan tidak keruh. Batas maksimal kekeruhan air layak minum menurut Permenkes RI nomor 416 tahun 1990 , adalah 5 skala NTU. Kekeruhan air disebabkan oleh partikel-partikel yang tersuspensi di dalam air yang 
menyebabkan air terlihat keruh, kotor, bahkan berlumpur. Bahan-bahan yang menyebabkan air keruh antara lain tanah liat, pasir dan lumpur. Air keruh bukan berarti tidak dapat diminum atau berbahaya bagi kesehatan. Namun, dari segi estetika air keruh tidak layak atau tidak wajar untuk diminum.

Dari hasil penelitian ini sampel air yang digunakan adalah air yang sangat keruh dengan tingkat kekeruhan 100,04 NTU. Setelah dilakukan penyaringan dengan menambahkan arang aktif cangkang kelapa sawit (Elaeis guineensis) $10 \mathrm{Cm}$ terjadi penurunan tingkat kekeruhan dengan rata-rata 40,04 NTU. Kalau kita melihat selisih tingkat kekeruhan dari 100,04 NTU menjadi 40,04 NTU adalah 60 NTU yang merupakan selisih yang besar.

Analisa tingkat kekeruhan air terlihat bahwa pengurangan tingkat kekeruhan dengan proses filtrasi terjadi penurunan yang cukup tinggi. Mengingat fungsi dari saringan pasir lambat dan juga arang aktif sebagai alat penyaring dan penyerap dari partikel-partikel air yang menyebabkan air tersebut menjadi keruh. Penyerapan yang paling optimal pada penelitian ini adalah dengan penambahan arang aktif cangkang kelapa sawit (Elaeis guineensis) $10 \mathrm{Cm}$ dengan penurunan tingkat kekeruhan dengan rata-rata 40,04 NTU.

Salah satu upaya untuk membersihkan air sumur yang keruh adalah dengan cara penyaringan dengan membuat saringan pasir lambat yang diisi dengan kerikil, ijuk dan pasir. Selanjutnya dengan penambahan arang aktif memberikan hasil yang optimal dalam proses penyaringan karena fungsi dari arang aktif sebagai penyerap (Mubaraq dan Chayatin, 2008),

Penelitian Sembiring dan Sinaga (2003), menjelaskan bahwa luas permukaan arang aktif berkisar antara 300-3500 $\mathrm{m} 2 /$ gram dan ini berhubungan dengan struktur pori internal yang menyebabkan arang aktif mempunyai sifat sebagai adsorben. Arang aktif dapat mengadsorpsi gas dan senyawa-senyawa kimia tertentu atau sifat adsorpsinya selektif, tergantung pada besar atau volume pori-pori dan luas permukaan. Daya serap arang aktif sangat besar, yaitu 25-1000 persen terhadap berat arang aktif.

Penelitian Pujiarti dan Sutapa ( 2005), yang berjudul Mutu Arang Aktif dari Limbah Kayu Mahoni (Swietenia macrophylla. King) sebagai Bahan Penjernih Air menemukan bahwa kualitas air yang telah dijernihkan dengan arang aktif menghasilkan penurunan kadar Fe sebesar 93.97 persen, kadar Mn sebesar 75 persen dan kadar Zn mencapai 100 persen.

\section{pH (Derajat Keasaman)}

Hysocc (2013), mengatakan pH adalah derajat keasaman yang digunakan untuk menyatakan tingkat keasaman atau kebasaan yang dimiliki oleh suatu larutan. Nilai $\mathrm{pH}$ dibawah 7 bersifat asam dan di atas 7 bersifat basa. Air yang bersifat asam dapat menyebabkan gatal-gatal, diare dan kulit bersisik (Suhendra dkk, 2012)

Berdasarkan hasil yang diperoleh pada Tabel 2 terlihat pada proses filtrasi tanpa penambahan arang aktif terjadi penurunan nilai $\mathrm{pH}$ dengan dugaan proses filtrasi dengan saringan pasir lambat dapat menurunkan nilai $\mathrm{pH}$ air, sedangkan pada proses filtrasi dengan penambahan arang aktif terjadi penambahan nilai $\mathrm{pH}$ yang cukup tinggi dengan demikian selain digunakan sebagai bahan penyerap, diduga arang aktif juga dapat digunakan untuk menaikkan nilai $\mathrm{pH}$ pada air. Dapat dikatakan proses filtrasi dengan menambahkan arang aktif cangkang kelapa sawit (Elaeis guineensis) cukup baik untuk memperbaiki kualitas air yang bersifat asam.

Suhartana (2006), mengatakan pada hasil $\mathrm{pH}$ didapatkan terjadinya penurunan nilai $\mathrm{pH}$. Hal ini sebenarnya dapat dimaklumi karena dalam arang sabut kelapa juga mengandung garam- garam kalsium karbonat, yang pada waktu tertentu akan mampu terlarut dalam air. Oleh karena itu, pada waktu tertentu kadar kesadahan air akan konstan.

Selanjutnya Sudirjo (2006), menjelaskan gugus fungsi dapat terbentuk pada karbon aktif ketika dilakukan aktifasi yang terjadi interaksi radikal-radikal pada permukaan karbon dengan atom-atom seperti Oksigen dan Nitrogen, yang berasal dari proses pengolahan ataupun atmosfir. Gugus fungsi ini menyebabkan permukaan karbon aktif menjadi reaktif secara kimiawi dan mempengaruhi sifat adsorbsinya. Oksidasi permukaan dalam produksi karbon aktif akan menghasilkan gugus hidroksil, karbonil dan karboksilat yang memberikan sifat amfoter pada karbon, sehingga karbon aktif dapat bersifat sebagai asam maupun basa.

Penelitian yang dilakukan Jamilatun dan Setyawan (2014), menggunakan karbon aktif dari suhu aktivasi $800{ }^{\circ} \mathrm{C}$ menghasilkan air yang jernih, tidak berbau dan memenuhi $\mathrm{pH}$ standar air $(7,0-7,5)$.

\section{Bau Air dan Rasa Air}

Hasil analisis bau dari proses filtrasi menunjukkan bahwa dengan penambahan arang aktif cangkang kelapa sawit (Elaeis guineensis) dapat menghilangkan bau pada air tersebut (tabel 3). Ini disebabkan pada proses filtrasi partikel-partikel yang dapat menyebabkan bau pada air tersebut sudah tersaring dan juga fungsi dari arang aktif sebagai penyerap yang dapat menghilangkan bau pada air.

Hasil penilaian pada Tabel 4 menunjukkan bahwa pada proses filtrasi dengan menambahkan arang aktif cangkang kelapa sawit (Elaeis guineensis) menghasilkan air yang tidak berasa ini disebabkan bau lumpur yang ada pada kontrol telah disaring dan diserap dengan arang aktif sehingga menghilangkan rasa dari air tersebut dan memenuhi standar air bersih.

Suhartana (2006), mengatakan pada umumnya arang aktif digunakan sebagai bahan penyerap dan 
penjernih. Dalam jumlah kecil digunakan juga sebagai katalisator. Sifat adsorpsinya selektif, tergantung pada besar atau volume pori-pori dan luas permukaan. Daya serap arang aktif sangat besar, yaitu 25-100 persen terhadap berat arang aktif. Sehingga arang aktif dapat menyerap partikel-partikel yang dapat menimbulkan bau dan rasa pada air, sehingga dapat menghilangkan bau dan rasa pada air tersebut.

Secara keseluruhan penambahan arang aktif cangkang kelapa sawit (Elaeis guineensis) dalam proses filtrasi cukup efektif dalam memperbaiki kualitas fisik air sumur. Tentunya hal ini akan sangat bermanfaat bagi masyarakat untuk meningkatkan kualitas air untuk aktivitas sehari-hari.

\section{KESIMPULAN}

Hasil yang efektif pada proses filtasi air sumur dalam penelitian ini adalah dengan menambahkan arang aktif cangkang kelapa sawit (Elaeis guineensis) dengan ketebalan $10 \mathrm{Cm}$. Proses filtrasi dengan menambahkan arang aktif cukup baik untuk memperbaiki kualitas air yang bersifat asam dan memberikan hasil yang lebih optimal dalam meningkatkan kualitas fisik air sumur.

\section{SARAN}

Disarankan dilakukannya pengukuran luas permukaan arang aktif dan daya serap dari arang aktif cangkang kelapa sawit sebelum digunakan sebagai adsorben dalam proses filtrasi. 2). Disarankan pengukuran tidak hanya dari karakter fisik air tetapi juga pada karakter kimia dan biologi air.

\section{UCAPAN TERIMA KASIH}

Peneliti mengucapkan terima kasih kepada Laboratorium UPT Dinas Kesehatan dan Lingkungan Provinsi Riau dan Laboratorium Universitas Abdurrab Pekanbaru yang telah bersedia sebagai tempat pelaksanaan penelitian serta kepada semua pihak yang telah membantu sehingga penelitian ini dapat berjalan dengan baik.

\section{DAFTAR PUSTAKA}

DEPKES, R.I. Pedoman tehknis perbaikan kualitas air. DEPKES RI. Jakarta. 1992.

Hysocc. 2013. pH (Drajar Keasaman). http//id.m.wikipedia. diakses 5 Agustus 2015.
Jamilatun, S. dan M. Setyawan. 2014. Pembuatan Arang Aktif dari Tempurung Kelapa dan Aplikasinya untuk Penjernihan Asap Cair. Jurnal SPEKTRUM INDUSTRI Vol 12 No 1. Universitas Ahmad Dahlan Yogyakarta.

Moenif, E.M. 2012. Potensi, Pengembangan dan Target Implementasi Energi Terbarukan di Provinsi Riau.Dinas Pertambangan dan Energi Provinsi Riau.

Mubarak, W.I. dan N. Chayatin. 2008. Ilmu Kesehatan Masyarakat. Gresik: Salemba Medika.

Pujiarti R. dan J.P. Sutapa. 2005. Mutu Arang Aktif dari Limbah Kayu Mahoni (Swietenia macrophylla King) sebagai Bahan Penjernih Air. Jurnal Ilmu \& Teknologi Kayu Tropis Vol.3 - No. 2. Fakultas Kehutanan UGM, Yogyakarta.

Sembiring dan Sinaga. 2013. Arang Aktif. Jurnal Fakultas Teknik. Universitas Sumatra Utara.

Sudirjo, E. 2006. Penentuan Distribusi Benzema Toluena Pada Kolom Absorbsi Fixed - Bed Karbon Aktif. Fak. Teknik UI.

Suhartana. 2006. Pemanfaatan Temprung Kelapa Sebagai Bahan Baku Arang Aktif dan Aplikasinya untuk Penjernihan Air Sumur di Desa Belor Kecamatan Ngaringan Kabupaten Grobogan. Jurnal ISSN : 1410 - 9662 Vol 9 No 3. UNDIP.

Sulfami, W.F. 2010. Efektifitas Tanah Liat Sebagai Koagulan dalam Memperbaiki Kualitas Fisik Air Gambut. Jurnal Universitas Sumatra Utara.

Soemirat. J., 2000, Kesehatan Lingkungan, Gajah Mada Universitas Press, Yogyakarta.

Syahza, A. 2012-2013. Potensi Pengembangan Industri Kelapa Sawit. Peneliti dan Pengamat Ekonomi Pedesaan. Lembaga Penelitian Universitas Riau.

Suhendra, D.S., I. Marsaulina dan D.N. Santi. 2012. Analisis Kualitas air Gambut dan Keluhan Kesehatan pada masyarakat di Dusun Pulo Gombut Desa Sukarame baru Kecamatan Kuala Hulu Kabupaten Labuhan Batu Utara Tahun 2012. Departemen Kesehatan Lingkungan Fakultas Kesehatan Masyarakat. Universitas Sumatra Utara. 